\title{
Crop Protection and Its Effectiveness against Wildlife: A Case Study of Two Villages of Shivapuri National Park, Nepal
}

\author{
Sudip Pandey ${ }^{1}$ and Siddhartha Bajra Bajracharya ${ }^{2}$ \\ ${ }^{1}$ TESAF, University of Padova, Italy \\ ${ }^{2}$ National Trust for Nature Conservation, Lalitpur, Nepal \\ e-mail: environ.sudip@gmail.com
}

\begin{abstract}
A complex relationship between the residents and protected areas continue to be an obstacle to successful conservation of protected areas. Conflicts between park authority and people living around the park pose a threat to conservation. Moreover, crop depredation due to wildlife incurs a severe economic loss to communities living in the close vicinity of the park, affecting the livelihood and well-being of locals. Many studies have been carried out emphasizing the identification and quantification of crop damage, but studies highlighting the means used for the crop protection and their effectiveness are limited. This paper examines frequency of the crop damage by wildlife and efficacy of utilized management practices in Shivapuri National Park (SNP). Altogether 132 households were visited in two buffer zone villages namely, Sikre and Jhor Mahankhal of Shivapuri National Park, Nepal. The study suggested that crop depredation by wildlife was a function of several factors, namely, distance of the farmland from the park, size of the crop raiding animals, frequency of their attacks on the farmland, and the type of crops. Five different measures were identified by the communities which they regularly used to prevent crop damage. Both traditional as well as modern means were used by households to guard crops from invading wild animals. The means of crop protection from wildlife differed according to the type of animal and crop being protected. Biofencing and trenches were effective for the small animals. Watch tower "Machans" and throwing flaming sticks and making noises were the most effective and safest means of crop guarding from all kind of animals. Though crop guarding was intensive, no means were found to be able to prevent crop damage completely. Thus, site specific management strategies as well as technical and financial support from donor organizations would be most useful to minimize crop loss.
\end{abstract}

Key words: crop depredation, crop protection, human-wildlife conflict, protected areas, wildlife

\section{Introduction}

Protected area network has expanded rapidly since 1950 s, particularly in the developing countries. In many developed countries, successful attempts to conserve wildlife have resulted in an increase in wildlife population, particularly large mammals (Wells 1992). In the developing countries, protected areas are mostly surrounded by densely populated agricultural lands that result in escalating conflicts between local communities and park authorities over the land-use rights and practices (Nepal \& Weber 1994). Conflict issues are mainly related to peoples' livelihood, which are difficult to overcome (Ghimire \& Pimbert 1997).
Issues such as loss of extraction rights and losses due to wildlife interferences and lack of or limited financial compensation have been highlighted as the root causes of conflict between the local communities and conservation programmes (Baral \& Heinen 2007, Hill 1998, Karanth 2003). Similarly, illegal livestock grazing inside the park and transaction of forest products causes this imbalanced relationship (Studsord \& Wegg 1995, Tamang \& Baral 2008, Shrestha 1994). Among all these issues, damage to crops, livestock, property and also human life because of wildlife interferences have been regarded as one of the severe problems faced by protected areas 
worldwide (Heinen 1993, Nyhus et al. 2000, Perez \& Pacheco 2006, Rao et al. 2002, Weladji \& Tchamba 2003). Park-people conflicts due to wildlife interference in the livelihood of communities often jeopardize the relationship between local communities and the protected area itself. This deteriorating relationship between two key stakeholders threatens the long-term management of protected areas.

The protected area system of Nepal has received a wide recognition for involving communities in protected area management (Bajimaya 2005, Paudel 2002). The success of Chitwan National Park and Annapurna Conservation Area, for example, in providing income for park management and support for local people residing in buffer zone, is an outstanding example for many developing countries (Heinen \& Kattel 1992, Wells \& Sharma 1998). But still conflicts and displacements of local communities and their livelihood have been observed by conservation authorities (McLean \& Straede 2003).

Crop depredation is a major problem faced by villagers' surrounding all protected areas of Nepal. Researchers have identified elephant (Elephus maximus), rhino (Rhinoceros unicornis), wild boar (Sus scrofa), deer
(Axis axis) and monkey (Macaca mulatta) as the main raiders of crops in most of the protected areas of Nepal (Baral \& Heinen 2007, Oli et al. 1994, Strudsrod \& Wegge 1995). Similarly, in Shivapuri National Park, wild boar, deer and porcupine are the major crop depredators in the surrounding villages (Pandey 2009). These animals feed on varieties of crops, and the level of damage varies according to the distance between the park and the farmland. Local people use different means to guard against these wild animals such as bio-fencing, trenches, and different traditional means (tin-hitting, scare crow). No single measure is effective to guard against all type of crop raiders due to variations in size of wildlife popultion, their feeding habits, type of crops and distance to farmland. This study aims to identify major wildlife species causing crop damage and the frequency of the such damage. Moreover, it intends to measure the effectiveness of protection measure adopted by park authorities.

\section{Methodology}

\section{Study area: Shivapuri National Park}

The Shivapuri National Park (144sq. km) is situated on the northern fringe of Kathmandu valley and lies about $12 \mathrm{~km}$ away from the center of the capital city (Fig 1).

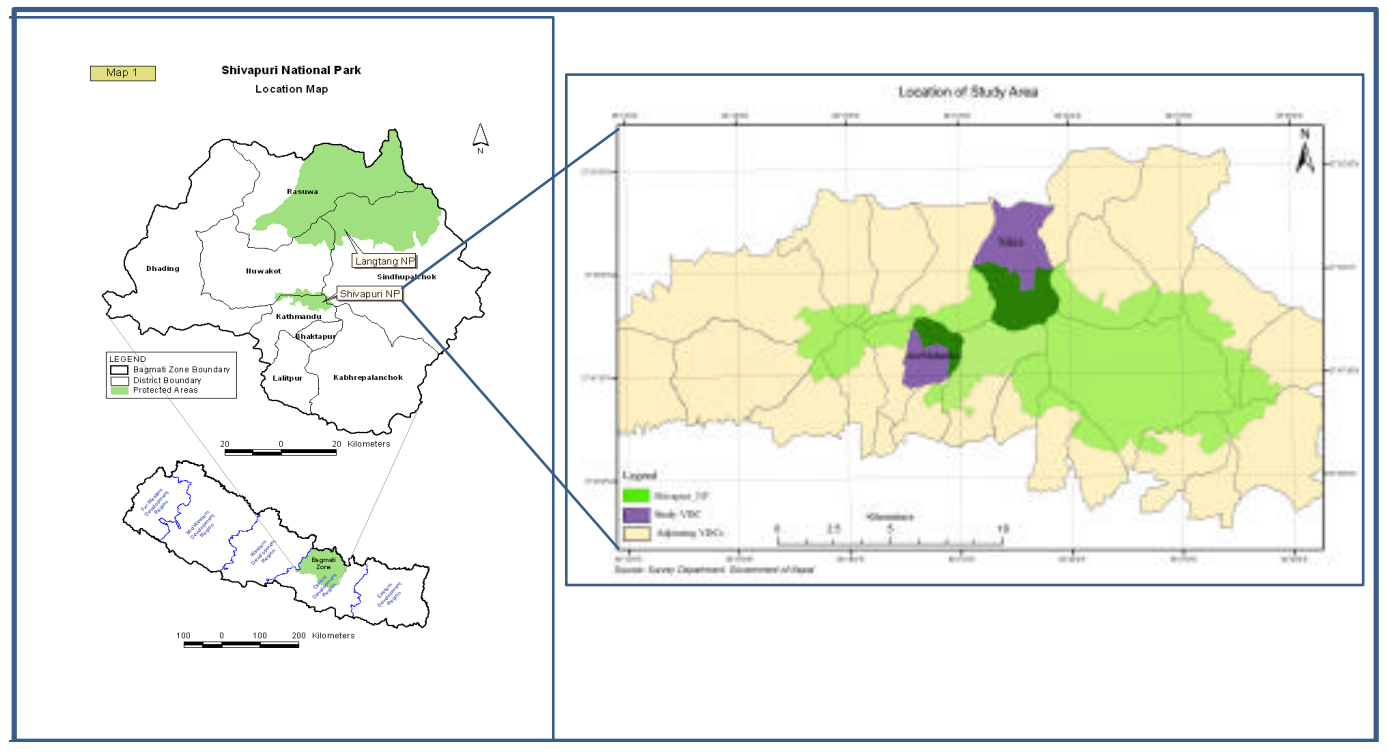

Fig. 1. Map showing the study area

Shivapuri lies in a transition zone between subtropical and temperate climates. The average maximum temperature reaches up to $19.75^{\circ} \mathrm{C}$ in summer and the average minimum temperature reaches up to $10.02^{\circ} \mathrm{C}$ in winter. The maximum rainfall $(691.70 \mathrm{~mm})$ occurs in July and it decreases considerably in winter. SNP has four types of forests which are distributed along the altitudinal gradient (Amatya 1993, Kattel 1993). They 
include: i) lower mixed hardwood (Schima-castanopsis) forest at $1,000-1,500 \mathrm{~m}$, ii) chir pine forest at 1,000 $1,600 \mathrm{~m}$, iii) Upper mixed hardwood forest at $1,500 \mathrm{~m}$ $2,300 \mathrm{~m}$, and iv) Oak forest at 2,300-2,700m. The park is home to threatened animals such as clouded leopard (Pardofelis nebulosa), rhesus monkey (Macaca mulatta), jungle cat (Felis chaus), goral (Naemorhedus goral), and Himalayan black bear (Ursus thibetanus). More than 177 species of birds, including at least 9 threatened species, 102 species of butterflies with a number of rare and endangered species, and 129 species of mushrooms have been recorded in the park's forest (Bhuju et al. 2007).

The two villages, namely Jhor Mahankhal on southern section and Sikre on northern section of the national park were selected for case studies. The basis of their selection were: i) location within the park boundary, ii) village development committee (VDCs) with the highest wildlife densities from where amount of illegal resources extraction would directly impact on the herbivore fauna shelter and diet, and thus indirectly affect the carnivore fauna that were the main focus of protection (Wegge et al. 2009).

\section{Household questionnaire}

The data collection was based on a survey using household questionnaire, which was carried out on February 2012. Altogether 132 households (comprising $16 \%$ of the total of 851 households) were included in the study using a stratified random sampling method where each ward (subdivision of local authority area) was considered as a stratum for sampling. According to Baker (1999), for the population of 10,000 or more, a sampling ratio (i.e. sample size/population) of $10 \%$ may be adequate to determine the sample size. The total population of Jhor Mahankhal and Sikre VDC was recorded over 10,000 (CBS 2007) thus, 16\% sampling ratio was taken for sample size.

According to Baral and Heinen (2007) farmlands located next to the national park boundary face a severed crop depredation compared to the farmlands far from the parks. Therefore, only households with farmland in the stretch of park boundary were selected for the survey following a simple random sampling method. For the household survey, six wards of Jhor Mahankhal and three wards of Sikre village were selected among the total of nine wards in each of these Village Development Committees. The wards were selected on the basis of survey done by Shivapuri National Park authorities as affected wards (NTNC 2004). Household lists were collected from voter's lists obtained from the ward office of each village. The questionnaire was usually addressed to household heads. When they were not available, the next willing member was interviewed. The household questionnaire consisted of four parts which included questions related to: i) socio-economic background of the household, land holding, livestock holding, livelihood strategies and source of income, ii) type of problems the household faced due to the park, iii) wild animals causing the damage, iv) means used for crop protection and their effectiveness. The entire questions were close-ended (asking the respondents to select the most plausible answer from the options already available), but households were given opportunity to elaborate on any of the issues raised. Questions were pre-tested in some households of Jhor Mahankhal and Sikre VDC and necessary modifications were made for data reliability. In order to gain the trust of the communities, local enumerators were hired and trained for the survey. Villagers felt comfortable when they were interviewed by one of their community rather than by the outsider; and interviews were carried out in Nepali and community's local languages. Park observations were carried out to identify crop depredation and the farmlands were also visited to make note of the usage of different means of crop protection. Observations were carried out by the author during the entire period of fieldwork (September to November, 2010) twice a day: early in the morning (5:00-6:00 am) and late in the evening (17:00-19:00 pm). During this observation period, the author identified wildlife's entry points to the farmland and observed the situation of the park and the villages. Likewise, severity of crop damage was measured by the ranking value known as Index of Relative Ranking (Miller 1986).

\section{Results and Discussion Socio-economic survey}

The distribution of households of the study area according to gender, age group, caste, occupation, education, income level is summarized in Table 1. The total numbers of male and female respondents were almost equal in both Sikre and Jhor VDC, i.e. 58.3\% males and $41.7 \%$ females in Sikre and $48.95 \%$ male and $51.04 \%$ female in Jhor. The age of the respondents ranged from 18 to 69 years. However, more than twothird $(85.4 \%)$ of the respondents were from the age 
group of 18 to 59 years. Ethnic composition of the respondents was found to be heterogeneous. The respondents were from different caste/ethnic groups comprising Brahman, Chhetri, Tamang, Newar, Gurung, Magar, Lama, Dalit and so on. More than half of the respondents were Gurung in Sikre and Brahman in Jhor. The occupation of majority of the respondents was agriculture. In total, $94.4 \%$ of the respondents from Sikre and $72.9 \%$ from Jhor were dependent only on agriculture. Res ts of the respondents were involved in government services, business, housework and labor. About $72.2 \%$ of the respondents in Sikre and $57.2 \%$ in Jhor were found to be literate. In Jhor, up to class 10 attendants were $10.4 \%$ and School Leaving Certificate (SLC) and above attendant were $26 \%$. Overall literacy rate of the study area was found to be $61.36 \%$ which was higher than the national literacy rate (54.1\%) (CBS 2007).

Table 1. General socio-economic characteristics of the respondents

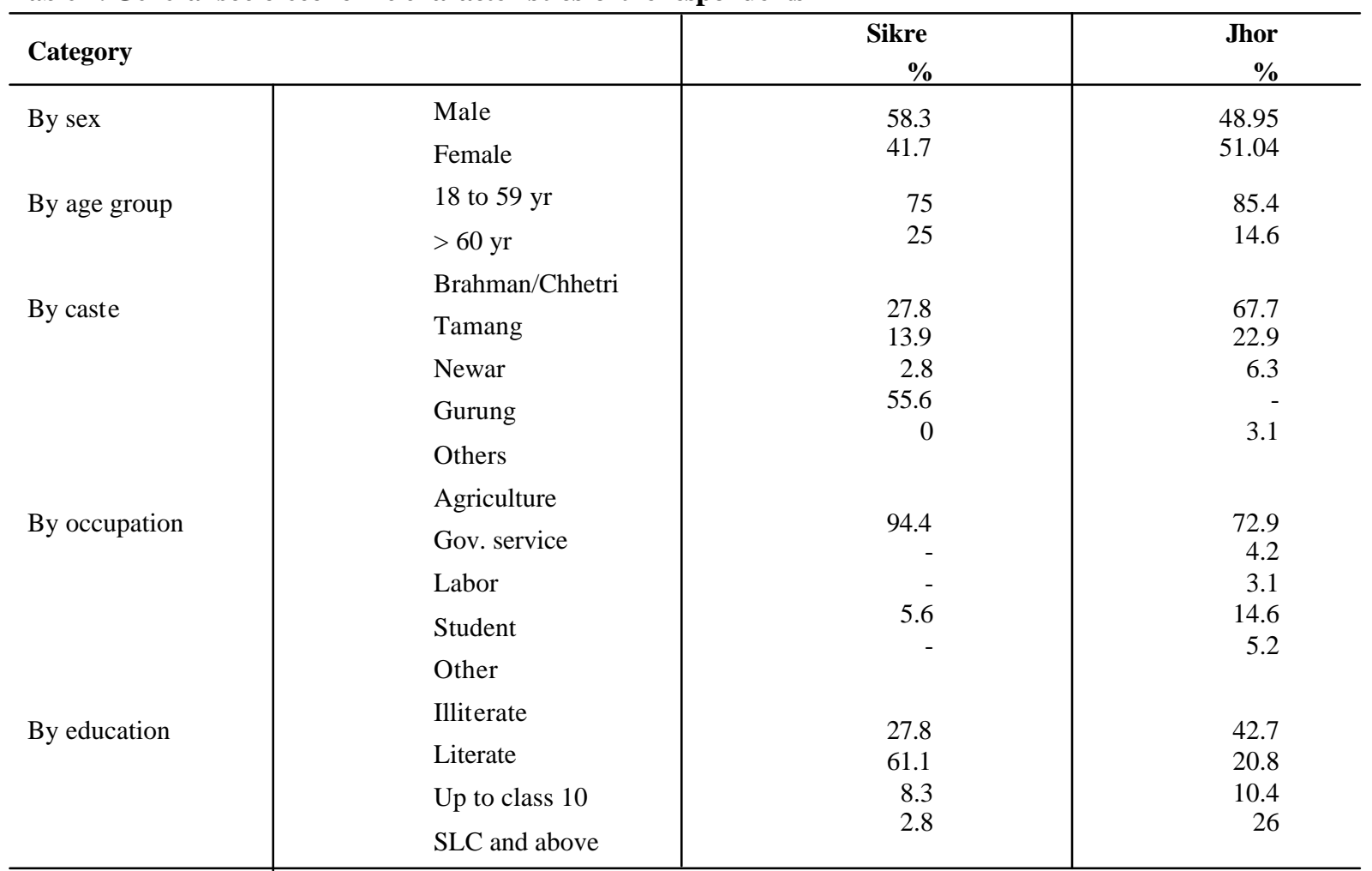

\section{Animals responsible for crop damage}

Households were asked about the problems they faced from the establishment of the protected area. Among the total respondents, $60 \%$ claimed crop damage and livestock loss were severe problems created by the wildlife in the park which directly impacted their livelihoods. They further added that, for protecting their crops, they stayed awake the whole night guarding their crops and chasing wild animals away from their households.

Six key problematic wild animals were identified by household's i.e. wild boar, monkey, barking deer, porcupine, common leopard and birds. Index of
Relative Ranking (IRR) was used to find the key problematic animals of the area. The IRR value ranges from 0 to 1: more the score, more the problematic the animal will be (Bhopal \& Last 2002). Among these, wild boar, monkey and porcupine posed severe livelihood threats to the surveyed households. The damage by birds, common leopard and barking deer was less significant. At Sikre, wild boar (0.75), and monkey (0.59) were dominant problem species compared to others, whereas wild boar (0.74) and porcupine (0.31) were more of the nuisance at Jhor Mahankhal. Wild boar almost reached at the status of pest at the surrounding villages of the national park (Fig. 2). 
Sudip Pandey/Crop Protection and Its Effectiveness......

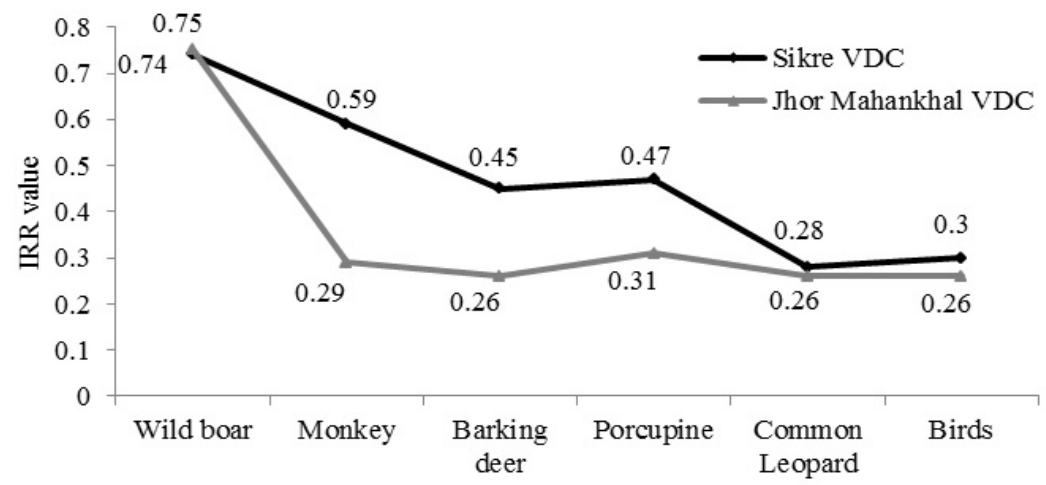

Fig.2. Key problematic wild animals

Crop damage with respects to distance of agriculture field from the nearest accessible forest

It was observed that most of the wild animals visited the farmland between dusk and dawn. Animals were active from $5.00 \mathrm{pm}$ in the evening to $6.00 \mathrm{am}$ in the morning. The study revealed that crop depredation has been reduced as compared to past 5 years. This reduction could be because of the reduced number of depredating animals or protection measure adopted by people. In addition, reduced agricultural activities in the field near to the park could also be the cause of reduced crop depredation. From the $\mathrm{z}$ test done to know the information about the wildlife damage in the
VDC, it was found that average crop damage was different in Sikre and Jhor VDC $\left(\mathrm{Z}_{\mathrm{cal}}\right.$ value 2.02, $\mathrm{Z}_{\mathrm{tab}}$ 1.96 at $5 \%$ level of significant i.e. $\left.Z_{\mathrm{cal}}>Z_{\mathrm{tab}}\right)$. It was observed that the frequency of visits by animals depends on the crops grown and the season. For instances, if there is potato in the farmland, wild boar continues to visit the farmland until it has destroyed all the potatoes, so the frequency of its visit will be daily within that period.

The average crop damage was found to be insignificant of distance between park and agriculture field. In case of Sikre, crop damage dependency with distance was found to be $10 \%$ and that of Jhor was $0.1 \%$ (Table 2).

Table 2. Relation between the crop damage and distance

\begin{tabular}{l|c|c|c|c}
\hline Study area & Constant regression & Rate of change & $\mathbf{R}^{2}$ Value & Dependency \\
\hline Sikre & 25.94 & -0.12 & 0.1 & 10 \\
Jhor & 16.42 & -0.02 & 0.001 & 0.1 \\
\hline
\end{tabular}

It is a general concept that damage by wild animals decreases with increase in distance but results from regression did not support the concept. In Sikre, it was found that in $1 \mathrm{~min}$ of walking distance, crop

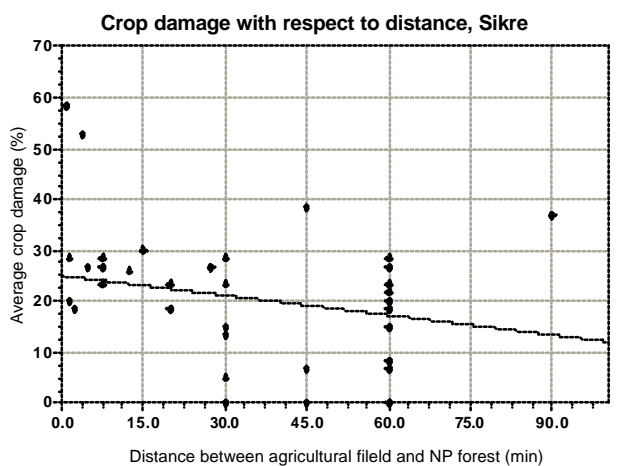

damage was found to be decreased by $0.12 \%$ ( 1 minute $=55$ Pace). Similarly, in Jhor, it was found that in $1 \mathrm{~min}$ of walking distance, the crop damage was found to be decreased by $0.02 \%$.

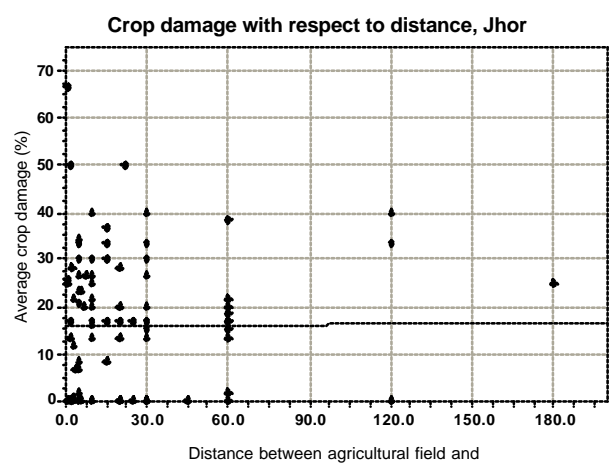

Fig. 3. Regression line showing relation between crop damage with respect to distance 
Sixty four percent of respondents from Sikre and $42.55 \%$ from Jhor had the middle level of crop damage. In Jhor, $22.34 \%$ of respondent observed the medium damage in near access to the forest, however, $33.33 \%$ observed it even at far access households. There was a sudden fall in crop damage from near to the middle type of access $(15-30$ minute walk; $0.5 \mathrm{~km}-1 \mathrm{~km})$ and it was not so from middle to the far access ( $>30$ minute walk; > $1 \mathrm{~km}$ ). This shows that mean crop damage has decreased with respect to increase in access to the forest. The numbers of protective measures were found to be increased with increase in damage. People facing the highest damage either left the land barren or they searched for the corrective measures. In Sikre, number of locals left the land barren due to the crop depredation problem and they migrated from the area in search of an alternative job. The willingness to adopt the corrective measures was increased with the increase in damage level.

\section{Methods used and their effectiveness for crop protection}

It was observed that a single crop was fed by more than one animal from its time of sowing up to the harvesting. Households have developed a combination of traditional as well as new preventive methods to minimize the crop loss around their farmland. Effectiveness was measured in terms of the quality of methods beings able to keep the target animals away from farmland. Bio-fencing with Euphorbia species as well as Jatropha species created a wall-like structure making entry difficult for small as well as large animals. Stone fencing was used as the permanent solution for reducing the wild animals movement in the beginning. However, the stone fencing that separates the park and village boundary was least effective these days as it was destroyed and damaged by both animals and communities leading to trespassing and damaging crops and well as illegal resource extraction. As it is easier for households to trepass the park for resource extraction, they do not complain to the park management for the maintenance of the fence. Neither does the park manager take any initiatives in renovating the damaged fences.

Similarly, tin hitting, group shouting and throwing flaming stick when used individually were effective but just for short periods. All the means described above were used for different animals and sometimes different combination were used to scare away the animals. For wild boar, net wires with dense vegetation cover were most effective as it confused the animals and restrict their movement. However, after few attempts it was not effective for wild boar as it could dig holes underneath and pass through the barrier and destroy the entire vegetables garden in one night. In some parts of the villages, people build watch towers for guarding of their crops during night. It was found that watch tower in combination with the other means were most effective. People also used growing unpalatable vegetables such as radish, chilli in the field near to the park. Thus, this reduced the conflict with the animals with the generation of the income by growing the vegetables.

\section{Nature and pattern of crop damage}

Crop damage was reported by all the respondents in the surveyed villages, however, the extent of damage varied locally. It was observed that crop damage was not found much significantly dependent on distance. It was found that crop depredation by wildlife was a function of several factors, such as the protection measure, type of crops and their frequencies of attack on the farmland and season. Studies of Newmark etal. (1994) in Tanzania and of Studsrod and Wegge (1995) in Nepal suggest that the seriousness of crop damage varied with distance from the park's border, specific location of farms, presence of physical barriers, wildlife population density and availability of forested areas outside the parks. The findings of this research are supported by previous studies in other protected areas worldwide that state numbers of factors play a role in crop damage by wildlife such as seasons and crop types (Schley et al. 2008), or distance of the farmland to the park (Cai et al. 2008) and different stages of crops (Vassant 1996). Our studies in the VDCs showed that crops were damaged not only by feeding but also by trampling and uprooting. This showed that the size of the crop raiders was also important in crop damage. Similar to the result, Perez and Pacheco (2006) noted that crop damage by frequent visitors did not cause the largest damage, it was generally caused by the large-bodied species. This implies that the severity of crop may be more due to wild boar and bear than chital and birds in the VDCs around SNP. This highlights the need to focus more on large-bodied species and their specific seasonal visits.

Crops were damaged not only by feeding, but also a considerable amount of damage was caused by 
trampling and uprooting. Together with the factors suggested by the above researchers, this study observed that the size of the crop raiders was also important in crop damage. Perez and Pacheco (2006) noted that crop damage by frequent visitors did not cause the largest damage, but it was generally caused by the large-bodied species (Naughton-Trever 1998). This implies that the severity of crop damage may be more due to the wild boar and bear than chital and the birds. This highlights the need to focus more on large -bodied species and their specific seasonal visits.

Different species of animals were found problematic in different villages. In Sikre and Jhor Mahankhal crop damage by wild boar was severe although ward specific problematic animals were different. Wild boar not only feed on crops but also uprooted the plants such as yam, potato, etc. Besides, birds, monkeys, and porcupine were also reported as serious pests to crops. The problem has become so severe that the farmers had to abandon areas of cultivated land. Ulak (1992), Kattel (1993), and Poudyal (1995) identified wild boar as a frequent crop raider and maize was the most raided crop by wildlife in SNP. While Gurung (2002) identified wild boar (major), bear, monkey, porcupine, rat and birds (minor) as crop raiders, which is paddy, wheat, maize, millet, potato, mustard and root crops in SNP. This study observed that households living in Sikre and Jhor Mahankal VDC faced severe economic losses (USD 10238/annum) due to these raiding wild animals. Poudyal (1995) estimated the total loss of USD 6995.45 per annum in Sundarijal VDC and the crops mostly raided by wild animals were maize, millet, paddy, wheat and root crops like potato, arum and sweet potato. Root crops were abandoned by the farmers because their high depredation by wildlife in SNP (Soti 1995). In addition to crop raiding, some isolated cases of livestock depredation by wild animals were also reported in the study area. Studies showed common leopard, wild cat and jackals as major predators for livestock (goat, cattle). Likewise, Purkait (2008) identified leopard (Panthera parades) and jungle cats (Felis chaus) as major predator for livestock in Sundarijal VDC.

\section{Means used by the communities to protect crops and their effectiveness}

As the surveyed households were facing severe crop loss due to a number of wild animals, they used different combinations of traditional and modern means to protect them. Five different means were identified during the survey, which were used regularly to prevent crop damage. The means differed according to the animals and crop being protected. Crop guarding through the use of watch towers combined with group shouting and throwing flaming sticks were found to be effective for short time. Similar, findings were observed in other protected areas of Nepal. Strudsrod and Wegge (1995) in their study at Bardia national park reported that guarding using different combinations of means was the most effective for crop protection. Similarly, at Chitwan national park Nepal and Weber (1995) stressed that crop guarding using watch tower was highly effective though, the group shouting and throwing flaming sticks were often dangerous. Their research also highlight that the presence of nearby forest in the form of Buffer Zone Community Forest (BZCF) worsened the situation further as these areas acted as an extension for animals to prepare for early intrusion. In Bardia, it was observed that crops in the farmland closed to the BZCF were damaged more than in other areas. In Sariska Tiger Reserve, India Sekhar (1998) also stressed that combinations of means were employed by households for effective crop protection. Although it was observed that guarding through the use of watch tower was most effective, financially viable and the safest means. It was a very intensive and time-consuming process. Crop guarding using watch tower was especially useful against wild boar and bear as these animals could charge back and even kill when they find humans in their way. Although noise making was effective for short period of time, it was hardly successful due to unpredictable frequency and intensity of wild animals. Also, Sitati et al. (2005) found that noise making through group warning, use of claps for early could only work for short time. Bio-fencing and net wires were useful for small animals like chital. Fencing alone was only temporarily effective for wild boar as after few visits it could pass to agricultural fields by digging holes beneath the fence (Sekhar 1998). One of the main problems of different means used by households was that they were all temporary which made wild animals move away to certain distance but they return when it was quite again. This momentarily nature of preventive methods worsened the damage over the years (Nepal \& Weber 1995).

Methods such as control hunting, translocation and cultivation of non-edible crops were carried out in the 
Nepal Journal of Science and Technology Vol. 16, No.1 (2015) 1-10

study area. However, these methods were not found to be effectives against the wildlife. Sitati and Walpole (2006) suggested that these methods need further research to ensure their effectiveness against without any additional costs to households and impacts to wildlife. People in study areas used deterrents including visual, chemical and acoustic repulsive substances but it did not work. Therefore, in addition to those methods, exchange of information among the farmers about different preventive methods could help in adopting varieties of techniques employed for crop protection. According to Sitati et al. (2005) this exchange of information could facilitate learning among communities and park management to support action for crop damage problems.

\section{Conclusion}

The damage to field crops caused by wild animals has been a highly topical issue and also one that has been discussed publicly. It was found that crop varieties, distance of the farm from the park boundary, and the surrounding ecology were the main factors in crop damage variation. Although different means were used to prevent crop damage, most of the means were only temporarily effective as animals were only driven away for few minutes to be expected to come back after things were quiet. Different means including traditional and modern means were used for different types of animals which implied no single means could be employed to all the villages. This highlights the need for site-specific management techniques to minimise the crop damage problem by wild animals. As households stated, a few crops avoided by wildlife provide economic benefits, park management should conduct further research on sustainability of those crops. In addition, exchange of information among farmers about different mitigating means, and a learning process within the park management could help to minimise the crop damage problems. Studies show that using different activities to effectively mitigate crop raiding and seem to be an appropriate response strategy.

\section{Acknowledgements}

Dr. Dinesh Raj Bhuju provided invaluable suggestions to improve sampling strategy and data collection plan. We are thankful to the Department of National Parks and Wildlife Conservation (DNPWC) and SNP for providing permission to carry out this research. We are also thankful to all the members of Community
Forest User Groups (CFUGs) and local people who provided valuable information to us.

\section{Reference}

Amatya, D. 1993. Study on forest vegetation analysis. Shivapuri integrated watershed development project. GCP/NEP/048/NOR. Page 5-19. () HMG of Nepal and FAO.

Bajimaya, S. 2005. Participatory conservation in protected areas of Nepal. Resources Himalaya Foundation, Kathmandu and IUCN World Commission on Protected Areas, South Asia. Pp. 27- 32.

Baker, T.L. 1999. Doing social research ( $3^{\text {rd }}$ Edn.), New York: McGraw-Hill Inc.

Baral, N. and J.T. Heinen. 2007. Resources use, conservation attitudes, management intervention and park-people relations in the Western Terai landscape of Nepal. Environmental Conservation 34: 64-72.

Bhopal, R. and J.M. Last. 2002. Concepts of epidemiology: an integrated introduction to the ideas, theories, principles and methods of epidemiology. Oxford: Oxford University Press.

Bhuju, U.R., P.R Shakya, T.B. Basnet and S. Shrestha. 2007. Nepal biodiversity resource book, protected areas, Ramsar sites and world heritage sites. ICIMOD, MoEST, Nepalnature.com, UNEP, Kathmandu, Nepal.

Cai, J., Z.G. Jiang, Y. Zeng, C.W. Li, and B.D. Bravery. 2008. Factors affecting crop damage by wild boar and methods of mitigation in a giant panda reserve. European Journal of Wildlife Research54:723-728.

Central Bureau of Statistics (CBS). 2007. Nepal living standard survey. National Planning Commission Secretariat, Government of Nepal.

Ghimire, K.B. and M.P.E. Pimbert. 1997. Social change and conservation: Environmental Politics and Impacts of National Park $s$ and Protected Areas. Earth scan.

Gurung, D.P. 2002. Wild boar (Sus scrofa, Linnaeus 1785) Distribution and Conflict between Park and People in Shivapuri National Park, Nepal. M.Sc. Thesis. Tribhuvan University, Kirtipur, Nepal.

Heinen, J.T. 1993. Park people relations in Koshi Tappu wildlife reserve, Nepal-a socioeconomic analysis. Environmental Conservation 20: 25-34.

Heinen, J.T. and B. Kattel.1992. Parks, people, and conservation a review of management issues in Nepal protected areas. Population and Environment 14: 49-84.

Hill, C.M. 1998. Conflicting attitudes towards elephants around the Budongo Forest Reserve, Uganda. Environmental Conservation 25: 244-250.

Karanth, K.K. 2003. Forest use and human-wildlife conflicts in Bhadra Wildlife Sanctuary, Karnataka, India. Tropical Resource Bulletin 22: 48-58. 
Kattel, B. 1993. A Study on Assessment of Wildlife Diversity and Crop Depredation in Shivapuri Watershed and Wildlife Reserve. Shivapuri Watershed Development Project. GCP/NEP/048/NOR National Consultant Report.

McLean and S. Straede. 2003. Conservation, relocation, and the paradigms of park and people management - a case study of Padampur Villages and the Royal Chitwan National Park, Nepal. Society and Natural Resources 16: $509-526$.

Miller, D.C 1986. A Handbook of Research Design and Social Measurements (third edition) Longman, New York.

National Trust for Nature Conservation (NTNC) 2004. Shivapuri Management Plan. Draft Report submitted to Department of National parks and Wildlife Conservation (Unpublished)

Naughton-Trever, L. 1998. Predicting patterns of crop damage by wildlife around Kibale National Park, Uganda. Conservation Biology 12: 156-168.

Nepal, S.K. and K.E. Weber. 1994. A buffer zone for biodiversity conservation-viability of the concept in Nepal Royal Chitwan-National Park. Environmental Conservation 21: 333-341.

Nepal, S.K. and K.E. Weber. 1995. Prospects for coexistence - wildlife and local people. Ambio 24: 238-245.

Newmark, W.D., D.N. Manyanza, D.G. Gamassa, and H.I. Sariko. 1994. The conflict between wildlife and local people living adjacent to protected areas in Tanzania: Human density as a predictor. Conservation Biology 8: $249-255$.

Nyhus, P.J., Tilson and R. Sumianto. 2000. Crop-raiding elephants and conservation implications at Way Kambas National Park, Sumatra, Indonesia. Oryx 34: 262-274.

Oli, M.K., I.R. Taylor and M.E. Rogers. 1994. Snow leopard Panthera uncia predation of livestock: an assessment of local perceptions in the Annapurna Conservation Area, Nepal. Biological Conservation 68: 63-68.

Pandey, S. 2009. Understanding Biodiversity Conservation and Vegetation of adjoining VDCs at Shivapuri National Park - A Case study of Jhor Mahankhal and Sikre VDC. M.SC. Thesis in Environmental Science, Tribhuvan University, Nepal.

Paudel, N.S. 2002. Integrating people and nature: A perspective for environmental conservation and livelihoods in the context of Nepal. Journal of forest and livelihood. 2:62-67.

Perez, E. and L.F. Pacheco. 2006. Damage by large mammals to subsistence crops within a protected area in a montane forest of Bolivia. Crop Protection 25: 933939.

Poudyal, P.R. 1995. An Assessment of Crop Depredation due to Wildlife in Shivapuri Watershed and Wildlife reserve (A case of Sundarijal V.D.C.). M.Sc Thesis in Zoology, Tribhuvan University, Kathmandu, Nepal, pp-54.

Purkait, S. 2008. Park-people conflict and its management in and around Shivapuri National Park: A case study of Sundarijal VDC. M.Sc. Thesis. Tribhuvan University, Kritipur, Nepal.

Rao, K.S., R.K. Maikhuri, S. Nautiyal, and K.G. Saxena. 2002. Crop damage and livestock depredation by wildlife: a case study from Nanda Devi Biosphere Reserve, India. Journal of Environmental Management 66: $317-327$.

Schley, L., M. Dufrene, A. Krier, and L. Frantz. 2008. Patterns of crop damage by Wild Boar (Sus scrofa) in Luxembourg over a 10 year period. European Journal of Wildlife Research 54: 589-599.

Sekhar, N.U. 1998. Crop and livestock depredation caused by wild animals in protected areas: the case of Sariska Tiger Reserve, Rajasthan, India. Environmental Conservation 25: 160-171.

Shrestha, B. 1994. Studies on Park-people Conflict, Investigation on Resolving Resources Conflict between Park Conservation and Adjoining Settlements in the Northeastern Boundary of RCNP. M.Sc. Thesis in Zoology, Tribhuvan University, Nepal.

Sitati, N.W., and M.J. Walpole. 2006. Assessing farm-based measures for mitigating humane elephant conflict in Transmara District, Kenya. Oryx 40: 279-286.

Sitati, N.W., M.J. Walpole, and N. Leader-Williams. 2005. Factors affecting susceptibility of farms to crop raiding by African elephants: using a predictive model to mitigate conflict. Journal of Applied Ecology 42: 1175 1182.

Soti, J. M. 1995. An Assessment of Crop Depredation due to Wildlife in the Neighborhoods in Shivapuri Watershed and Wildlife Reserve. M.Sc. Thesis in Zoology, Tribhuvan University, Kathmandu, Nepal, pp-82.

Strudsrod, J.E., and P. Wegge. 1995. Park - people relationships - the case of damage caused by park animals around the Royal Bardia National Park, Nepal. Environmental Conservation 22: 133-142.

Tamang, B. and N. Baral. 2008. Livestock depredation by large cats in Bardia National Park, Nepal: implications for improving park-people relations. International Journal of Biodiversity Science and Management 4: 44-53.

Ulak, N.P. 1992. Wild boar in Shivapuri Watershed and Management. Shivapuri Integrated Watershed Management Project GCP/NEP/048/NOR. National Consultant Report.

Vassant, J. 1996. Evolution of wild boar populations and damage to crops in France between 1978 and 1993. In: CIC Proceedings of Schwarzwild Symposium, Sopron, Ungarn, pp. 131-141.

Wegge, P., M. Odden, C.P. Pokharel, and T. Storaas. 2009. Predator-prey relationships and responses of ungulates 


\section{Sudip Pandey/Crop Protection and Its Effectiveness......}

and their predators to the establishment of protected areas: a case study of tigers, leopards and their prey in Bardia National Park, Nepal. Biological Conservation 142: 189-202.

Weladji, R.B., and M.N. Tchamba. 2003. Conflict between people and protected areas within the Benoue Wildlife Conservation Area, North Cameroon. Oryx 37: 72-79.
Wells M. 1992. Biodiversity, conservation, affluence and poverty: mismatched costs and benefits and efforts to remedy them. Ambio 21: 237-243.

Wells, M.P., and U.R.Sharma. 1998. Socio-economic and political aspects of biodiversity conservation in Nepal. International Journal of Social Economics 25: 226243. 